\section{Pacific Entomological Survey}

ON November 2, 1932, a statement of the work and objects of the Pacific Entomological Survey was made before the Royal Entomological Society of London, as a result of which a resolution was passed unanimously inviting Dr. S. A. Neave to write and commend the work in the name of this Society, of which he later became president. On November 26 of the same year an appeal was issued in NATURE $(130,802-3 ; 1932)$, and further generous support was, despite the depression, fortheoming from various sources in Hawaii and elsewhere. Then, in 1935-37, liberal grants through the trustees of the will of the late Viscount Leverhulme and through the British Museum (Natural History) enabled Mr. E. P. Mumford, director of the Survey, to accept Sir Edward Poulton's invitation to complete the present phase of the work in the Oxford University Museum, where Sir Edward's successor, Prof. G. D. Hale Carpenter, is extending the hospitality of the Hope Department. The work of the Survey is of interest to all countries the territories of which either surround or extend into the Pacific, for, as Dr. Neave points out in the letter referred to above, "a knowledge of the fauna of all the Pacific Islands may well be of the utmost value in the more cultivated and developed ones, in that it may give a clue to the origin of many of the local pests of the latter, and thus point to opportunities for devising their biological control".

THE work of the Survey is already well advanced, and some 150 papers have been submitted for publication in Hawaii and elsewhere. It was originally proposed to prepare for publication a résumé and analysis of the findings of the Survey, and a discussion of the bearings thereof on the problems of distribution of insects in the Pacific, but it is becoming increasingly apparent as a result of the researches in Oxford that such an analysis will, to be of any value, have to take into account, not only the fauna of the islands of the Pacific, but also that of other islands. In reviewing (NATURE, 130, $797 ; 1932$ ) a manuscript copy of "Entomological Researches in the Marquesas Islands" (afterwards published in V $\mathrm{V}^{\mathrm{e}}$ Congrès International d'Entomologie, pp. 431-450, Paris, 1933), Dr. Hugh Scott referred to certain groups that are said to be absent from the Marquesas, and stated that the authors, Messrs. Mumford and Adamson, regarded these gaps in the fauna as strong evidence against the existence in past ages of extensive land areas in the Pacific, but, as Dr. Scott points out, some of these groups are also absent from the faunas of islands not of volcanic and purely oceanic origin. Furthermore, some of these groups that are thought to be absent from the Marquesas have been taken in supposedly oceanic islands elsewhere. Though Cicadas are unknown in the Marquesas, a remarkable genus has been described from Samoa, which island group Prof. Buxton considers to be oceanic. Caddisflies and may-flies, supposedly absent from the Marquesas, have been taken in Samoa as well as in the 'crypto-oceanic' Canary Islands and Madeira, and froghoppers, which were not met with by Messrs. Mumford and Adamson in the Marquesas, are known from Tonga, Samoa, the Society Islands, and Rapa. In bringing these extensive studies to a focus in Oxford, and at Farnham House Laboratory by courtesy of Dr. Thompson, Mr. Mumford and his assistants have received every assistance and cooperation from specialists throughout the world. Correspondence concerning island faunas may be addressed to the Hope Department of zoology (Entomology), University Museum, Oxford.

\section{Progress towards Internationalism}

THE October-January number of Science and Society is devoted to a discussion of the conditions of progress towards internationalism. Prof. E. Jackh, in an article on "The Changing International Relations", stresses the necessity of development into supra-national relations. Supra-national science has made possible and indeed necessary the organization of an international society. The tempo of such development, in which science shows the way, is determined by the extent to which humanity values technical civilization, science and their worldchanging effect as bursting asunder the frontiers between peoples. Prof. H. J. Fleure contributes an article on "Society and Liberty" in which he shows that society must be studied ecologically with a deep realization that no one has the whole truth; we are all seekers, and the truth is far above us all. $\mathrm{He}$ urges that it is our duty, in the name of science, to plead for freedom of conscience not only as an essential for scientific thought, but also as the only way in which in the long run society can keep in touch with the ever-flowing changes in the world. "Anthropology and racialism" is the subject of an article by J. C. Trevor, who, directing attention to some of the inherent difficulties in the consideration of problems of race, points out the danger to world peace which the accentuation of racial disparities may offer if identified with nationalistic aspira. tions.

Adrian Stephen's article on "War and Emotional Development" discusses some difficulties in a supranational authority and suggests that a hopeful line of progress lies in learning to regard countries or nations as pieces of machinery with definite functions for the promotion of human happiness rather than as idealized mothers and fathers. The application of science to political and international affairs at the present juncture is urged by C. A. Mace, in a thoughtful article "Planning Peace", to be less a matter of using specific material from the relevant social sciences than of infusing politics with some respect for the scientific spirit and the scientific point of view. Mr. Mace stresses the need for a system of publication, without fear or favour, of tested matters of fact. as essential to restore public confidence and to give intelligence to public judgment. R. H. Pender's survey of the political phases of Western Society leads him to the conclusion that any reintegration of society has to be achieved consciously 
and can only be tackled after an adequate idea of the nature of a society has been gained. This is in the first place a task for social science, since science alone has sufficient authority to get its conclusions adopted universally as a basis for action.

\section{Science and University Teaching}

AN article by Dr. W. H. George on "Science and University Teaching" in the New University of November, emphasizing the value of the widespread use of scientific methods in dealing with the social problems of to-day, points out that an education which includes one or more sciences does not necessarily foster scientific action. Even a knowledge of science up to university degree standard does not necessarily guarantee ability to think or act scientifically within the scope of the sciences studied. While, however, teaching is the best way of promoting the use of the scientific method, Dr. George points out that, in general, science but no scientific method is taught to science students and that scientific method, but no science, is taught to a small proportion of arts students and this teaching is separated from that of the student's main subject of study.

\section{National Forest Park near Snowdon}

A commixteE was appointed by the Forestry Commissioners on March 31 last to advise as to the steps which might be taken to form a national forest park on their properties in the vicinity of Snowdonia. It has now issued its report on the "National Forest Park Committee" (H.M. Stationery Office, 1937). The Forestry Commissioners had expressed an intention of designating areas, such as the one here under consideration, 'National Forest Parks'. It is pointed out that this type of park has no affinity with the 'National Park' as described in the report of the National Park Committee. The area here in question is the Gwydyr Forest of about 18,000 acres. The Forest forms a fringe of the wild and open mountain land culminating with the Snowdon range with its large stretches of foothills and rough grass, heather and rock-strewn spaces. The central Snowdon region is mostly in private ownership. The land in Gwydyr Forest which has been, or will be, planted by the Forestry Commissioners comprises about three. quarters of the area and forms the lower slopes on the east and south-east of the Snowdon range, in which group of mountains is included the Glyders and Carnedd mountains. There are numerous roads, tracks and footpaths, many of which afford delightful walks, climbs and views. The district includes some of the finest mountain scenery in North Wales and attracts a very large number of holiday-makers in the summer. The larger part of the Forest is held by the Commissioners on long leases subject to certain reservations. Local hostels exist, and certain other facilities in this respect and camping facilities are recommended, it being suggested that Government be asked to provide funds for the Commissioners' use in these developments. Such funds should surely be obtainable from the region which will benefit by the provision of this national forest park.
Acquisitions at the British Museum (Natural History)

Among the specimens presented to the Department of Mineralogy of the British Museum (Natural History) is a collection of about three hundred rock and mineral specimens, made by Mr. H. St. J. B. Philby, between Mecca and Mukalla, during his last journey of exploration through West and South. West Arabia. The collection is not only of academic interest. There is evidence of the presence of oil in the richly bituminous limestones and oil-soaked shales outcropping in the neighbourhood of Shabwa, and farther north, near Jizan, Mr. Philby collected specimens of hæmatite, an important iron-ore. This mineral is also present in several quartz-reefs, of which he brought back samples. By his careful and complete field-records of each occurring type, $\mathrm{Mr}$. Philby has brought to light a number of salient features in the geological structure of a region previously unknown to Europeans, and has made it possible to prepare an approximate geological map of the region through which he travelled.

\section{Vital Statistics in Great Britain}

ACCORDING to a return published by the RegistrarGeneral, the birth-rate in England and Wales during the year 1937 is provisionally estimated at 14.9 live births per thousand of the population, and the crude death-rate at 12.4 deaths per thousand of the population. The number of deaths of children under one year, per 1000 live births, was 58. The birthrate for 1937 is 0.1 above that for $1936,0.2$ above that for 1935 and 0.5 above that for 1933 the lowest on record. The crude death-rate is the highest recorded since 1929 and is 0.3 above that of 1936, an increase which is largely associated with the heavy influenza mortality of the first quarter of the year. The infant mortality is 1 below that of 1936 , and only 1 above that of 1935-the lowest recorded.

\section{Rheumatic Fever as a Protozoal Disease}

Dr. G. Arbour Stephens, 61 Walter Road, Swansea, referring to a recent Colonial Office Medical Report on the Falkland Islands, states that although the weather there is described as very damp and "permanent October" weather, and although the houses are damp, the soil acid, the food so poor that the school children wear dentures, and septic tonsillitis (due to Streptococcus) is so common, nevertheless rheumatic fever does not occur. This, he claims, supports the view that rheumatic fever is due to a protozoon (something like the malarial parasite), for the necessary insect carriers, such as harvest bugs, midges and fleas do not exist on the Islands.

\section{Current Titles}

WE have received the first part of a new monthly journal, Current Titles, published by Engineering Journals, 928 Broadway, New York, the subscription being 3 dollars yearly (4 dollars outside the United States). The journal gives the tables of contents of a large number of scientific, technical and engineering journals in English. We note that these include 